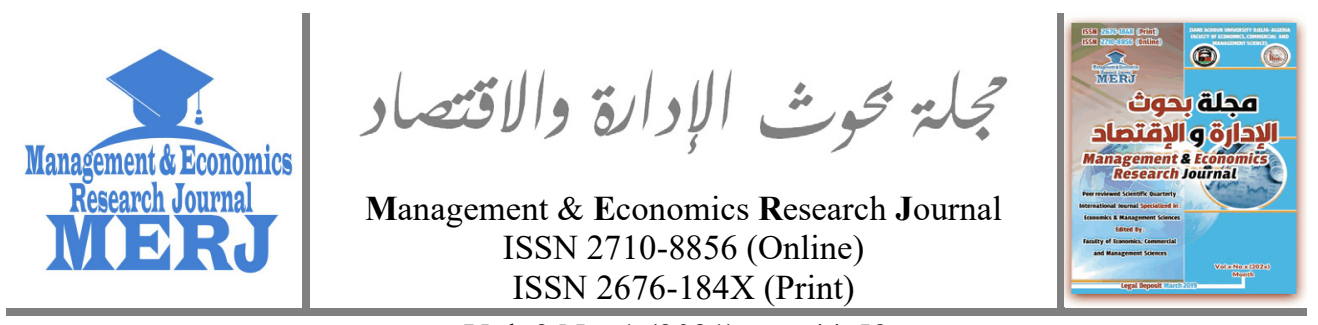

Vol. 3 No. 1 (2021), pp. $44-59$

https://doi.org/10.48100/merj.2021.155

Check for updates

\title{
Tourism, Trade and Self-employment Growth in West Africa: Evidence from Ghana, Nigeria and Cote d'Ivoire
}

\author{
Jimoh Olakunle Saka 1 \\ ${ }^{1}$ Senior Lecturer, Department of Economics, Lagos State University, Ojo (Nigeria) \\ $\bowtie$ jaystatistics@yahoo.com
}

Received: 07-02-2021

Accepted: 06-03-2021

Published online: 10-03-2021

\section{How to Cite:}

Saka, J. O. (2021). Tourism, Trade and Self-employment Growth in West Africa: Evidence from Ghana, Nigeria and Cote d'Ivoire. Management \& Economics Research Journal,3(1), 44-59. https://doi.org/10.48100/merj.2021.155

\section{Abstract:}

This study attempts to evaluate the relationship between tourism and trade and self-employment growth in Ghana, Nigeria, and Cote d'Ivoire using a time series of data spanning 1991-2019. In this study, an applied GMM approach was employed. Results show that export and import trade, development assistance, and personal remittance flows significantly spur self-employment during the study period, while indicators of tourism activities represented by the number of tourist arrivals retard the growth of self-employment but increase export trade in these countries. On this basis, the business atmosphere and infrastructural facilities should be improved to sufficiently boost the relationship between trade and tourism and spur selfemployment growth in these countries.

Keywords: Tourism, Trade, Self-employment, GMM.

JEL Codes: Z30, F10, J21.

• Corresponding author: Department of Economics, Lagos State University, Ojo (Nigeria) (Nigeria). [凹jaystatistics@yahoo.com]

(C)2021 the Author(s). This is an open-access article distributed under the terms of (CC BY-NC 4.0) which permits use, distribution and reproduction in any medium, provided the original work is properly cited and is not used for commercial purposes. 


\section{Introduction}

For developing countries such as Nigeria, tourism serves as a means of generating income and remains a key contributor to the economic size and a catalyst for backward and forward linkages. From the global macroeconomic view, tourism annually facilitates people's movement across international borders. It has been regarded as the world's growth engine through the globalization of goods and services, increasing leisure time, technological and transport revolution, and encouraging the middle classes. Besides tourism entrepreneurship, economic benefits include income generation through taxes levied on tourists, foreign exchange earnings, easing the balance of payment problems, economic diversification, and employment generation within rural and remote areas (Ekanayake \& Long, 2012). So far, the tourism sector provides one-tenth of worldwide GDP and employment, and aside from chemicals and fuel, it is the third-largest sector in the world (UNWTO, 2018).

International tourism has experienced improvement towards the second half of the 20th century and early in the 21 st century despite the emergence of obstacles, including terrorist activities, natural disasters, and growing health hazards. In the $1950 \mathrm{~s}, 100 \%$ of tourism flows were linked to 15 countries, and by the 20th century, tourism had become part of many countries' trade balances. At one point, the top 15 countries accounted for just $60 \%$ of all international flows. Webster, Fletcher, and Hardwick (2007) emphasize intra-industry trade (IIT) through a multi-country analysis and observe that Indonesia, Sri Lanka, Greece, and Mexico had the highest IIT, along with some developed economies. Some developed economies, such as Japan and Germany, are identified with the lowest values of IIT. It is, therefore, plausible to assume a relationship between international tourism and trading in goods as it facilitates an increase in international trade since goods can be transported from and to the destinations of interest (Tsui \& Fung, 2016).

Global tourism accounts for approximately $10 \%$ of the gross domestic product (GDP), translating to about US\$7.5 trillion, and can bring about 1 out of 11 jobs. The Economic significance of tourism is linked partly to the upcoming sustainable development goals of 2030. It is seen as a pointer to major development tools for poverty alleviation and sustainable development (González, 2017). As of 2014, the total earnings by the LDCs in exports from international tourism reached US $\$ 16.4 \mathrm{~b}$, translating to about $7 \%$ of the total exports. This, therefore, gives LDCs competitive options in global economic relations. In the same vein, trade contributes to tourism 
development through increasing integration between countries, resulting in investment in infrastructures such as transportation, linguistics, and technology, thereby making travel much easier and more interesting (Chaisumpunsakul \& Pholphirul, 2018; Santana-Gallego et al., 2011).

Despite many positive externalities the tourism business brings to participating countries, it is not without some demerits. In Africa, just as in every other part of the world, the level of mistrust among participating agents, such as various smuggling acts, engagements in illegal activities, etc., expose the countries to external attacks in the form of travel bans and warnings. Several movements abroad have been made through illegal means without a necessary travel document, and such attempts have led to untimely deportation, thereby defeating the tourism trade ambition. This retards economic progress that would have been made through tourists' activities. Based on the World Development Indicator database, the trade share in total GDP between 1960 and 2019 has been below expectation to drive tourism positive intervention into the economies of Cote d'Ivoire, Ghana, and Nigeria with respective $32.6 \%, 31.4 \%$, and $14.4 \%$ of their respective GDP.

In 2015-2017, Cote d'Ivoire receipts from tourists' activities amounted to $1.75 \%$ of the total export and $9.94 \%$ of the total exports for Ghana during 1995-2018, while Nigeria received $1.25 \%$ for the same period as Ghana. These low receipts appeared insufficient to facilitate tourismrelated employment activities, including hoteling, accommodation, business trips, and self-employment share in total employment. During 1991 -2019, Ghana only had an average of $5.10 \%$ of employers' total share in total employment, being the highest, followed by Nigeria, recording an average of $3.53 \%$. Similarly, trade integration, which can boost infrastructural development, including transportation, technology, etc., to foster tourism activities within these countries, is still low. Besides, the interaction between trade and tourism activities is yet to sufficiently boost employment as expected, going to the statistics above. The current research becomes highly motivated by the economic significance of tourism in boosting employment opportunities, for which trade also becomes germane. Besides, tourism is also given top consideration in the sustainable development plan of 2030; hence it becomes relevant to improve trade integration further to boost tourist attraction and employment growth. Subsequently, this paper examines the trade-tourism relationship and the employment effect of trade and tourism in Cote d'Ivoire, Ghana, and Nigeria. 


\section{Literature review}

As a good guide on tourism entrepreneurship business, earlier literature surveys have come up with various issues relating to tourism entrepreneurship (Bryon, 2012); Entrepreneurship as a drive towards making tourism business benefits (Taskov, Metodijeski, Dzaleva, \& Filipovski, 2011); tourism entrepreneurship as a factor enhancing the development of social life of social communities and touristic services (Rusu, Isac, \& Cureteanu, 2016). The consequence of neoliberal policies and globalization is that export should be a major strategy in many developing countries (Bhagwati, 1978); hence, policies for implementing trade increases became necessary. These policies, including (facilitating human and property mobility, simplifying border operations, etc., also stimulate tourism development.

Researchers have identified the role of international trade theory in the economics of tourism over time. Sinclair and Stabler (1997), among others, evaluate the relevance of comparative advantage theory to international specialization in tourism entrepreneurship. Besides, they also discuss the role trade theories, for example, those of intra-industry trade relating to imperfect competition, product differentiation, and scale economies, play in the tourism business.

In the export-led growth (ELG) theory framework, tourism enhances the existence of new models because it involves goods and services conventionally not traded at the international level. In line with this, tourism-led growth theory (TLG) is therefore given more recognition (Balaguer \& Cantavella-Jorda, 2002). Compared to the ELG, TLG plays very relevant roles in underdeveloped countries because it recognizes opportunities such as natural and cultural beauties that seem not unique in the developed world to be utilized (Balaguer \& Cantavella-Jorda, 2002). While tourism encourages trade flows, trade can also facilitate tourism development. Aside from facilitating consumption, tourists foster export growth through the demand for goods and services produced in the host domestic economy. Consequently, such products can gain access to the market in their home countries, or the business opportunities they observed during their foreign visits may become useful upon returning to their home countries (Fischer \& Gil-Alana, 2009).

Trade between countries can serve as a medium through which tourists find goods and services familiar to them in their own countries, attracting tourists (Khan, Toh, \& Chua, 2005; Kulendran \& Wilson, 2000; Santana-Gallego et al., 2011). Either way, such opportunities may result in 
employment and create a multiplier effect on GDP growth. Moreover, some theoretical reasons that bilateral trade can increase the share of tourism demand have been argued. First, bilateral trade can lead to a preference for home-country products, and second, bilateral trade helps reduce the costs of transactions between home and host country (Leitão, 2010). Transaction costs can be reduced through cultural, historical, and geographical proximity, promoting tourism entrepreneurship. On the other hand, theoretically, tourism is observed to have some indirect impact on trade increase which could be through the import of necessary raw materials to enhance the production of tourist products and services, thus improving the image of the region in question by transferring information about the region which subsequently leads to outstanding business opportunities (SantanaGallego, Ledesma-Rodrı 'guez, \& Pe 'rez-Rodrı 'guez, 2011). Generally, literature on tourism demand highlights relevant factors, including transport costs, price, income in tourism-engaging countries, and population, which may capture the market size. The population is one of the factors that capture population changes. The literature emphasizes that population has some correlation with immigration. (Witt \& Witt, 1995; Oigenblick \& Kirschenbaum, 2002). This is so because immigrants are considered to prefer the home-country products, which subsequently lowers transaction costs. Some studies conclude that the respective immigrants can promote tourism in a host country with family and friends (Oigenblick \& Kirschenbaum, 2002; Dwyer et al., 1992).

Earlier research on trade believes that international trade theory is more or less an international localization theory. The potential to create employment has become a great impression among tourism supporters. However, manufacturing industry development contributes immensely to total output growth but with few employment opportunities. The spread of the benefits of industrialization through income from employment opportunities which is grossly inadequate becomes a big challenge to industrial policy. Some research studies have examined the relationship between trade and tourism and their effect on employment growth (Khan et al., 2005). The relationship between trade and tourism confirms the influence of international trade on tourism demand for the US economy. Turner and Witt (2001) carry out a study for New Zealand with findings that international trade significantly impacts business tourism. Aradhyula and Tronstad (2003) demonstrated the efficiency of business trips in border trade between the US and Mexico.

In contrast, Tsui and Fung (2016) maintained that business travel and trade indicate some reciprocal link between Hong Kong, China, Taiwan, 
and the United States. Shan and Wilson (2001) studied the relationship between trade and tourism between China and Australia, the United Kingdom, and the USA. They find a bi-directional relationship between trade and tourism using the VAR method.

\section{Research design}

The theoretical framework emanates from the tourism-economic base analytical framework. Theoretically, it is asserted that a stable relationship exists between basic and service jobs such that a change in basic jobs $\left(E_{b}\right)$ facilitates a predictable change in service jobs and, consequently, in total employment. Expansion in basic activities leads to an increase in non-basic jobs, and overall employment $\left(E_{t}\right)$ grows by the same multiple $M$, the employment multiplier as described in equation (1) as follows:

$$
\begin{aligned}
& E_{t} \propto E_{b} \\
& M=\frac{E_{t}}{E_{b}}
\end{aligned}
$$

The economic impact of tourism may be viewed from its multiplier effect not through its conventional terms as the flow of income but in the form of tourists' expenditure into the respective economies. Such expenditure is transformed into income and /or employment for the economy. Henderson and Cousins's (1975) income multiplier model embraces direct regional income generation, indirect regional income generation, and induced income generation and follows the following patterns.

$$
M_{r}=\alpha+\beta+\sigma
$$

Where $\alpha$ is direct regional income generation per dollar (modified to suit Nigeria currency denomination) of tourist expenditure.

$\beta$ is indirect regional income generation per dollar of tourist expenditure and;

$\sigma$ reflects the induced regional income generation per dollar of tourist expenditure. But:

$$
\alpha=\sum_{j=1}^{J} \sum_{i=1}^{I} M_{j i} Y_{d_{i}}
$$




$$
\begin{aligned}
& \beta=\sum_{j=1}^{J} \sum_{i=1}^{I} M_{j i}\left(Y_{i}-Y_{d_{i}}\right) \\
& \sigma=(\alpha+\beta) M \frac{1}{1-L \sum_{i=1}^{J} M_{i} Z_{i} Y_{i}}
\end{aligned}
$$

Equations (3), (4), and (5) represent direct, indirect, and induced regional income models. With appropriate merging and obtaining the complete regional model, we get the following:

$$
I_{r}^{c}=\sum_{j=1}^{J} \sum_{i=1}^{I} N_{j} Q_{j} M_{j i} Y_{i} \frac{1}{1-L \sum_{i=1}^{J} M_{i} Z_{i} Y_{i}}
$$

Equation (6), $I_{r}{ }^{c}$ is the total income generated within the region from tourism activities.

$N_{j}$ is the number of days in the region spent by the $j t h$ tourist type and $Q_{j}$ reflects the total daily expenditure by the $j$ th tourist type and other terms. $N_{j}$ and $Q_{j}$ indicates the multiplicand, while other parameters signify other multiplication processes.

The employment generation model assumes a direct relationship between turnover and employment level. Based on Henderson and Cousins (1975), the regional employment multiplier is embedded in three components. These are direct employment emanates from those firms which receive tourist expenditure; indirect employment, which emanates from other businesses with their turnover being augmented with purchases by the original business and likewise employment which emanates from all businesses due to increased turnover from residents' expenditure of the factor incomes being generated by the regional multiplier process. The following identity follows thus:

$$
M_{r}=a+b+c
$$

Where $M_{r}$ is the regional employment multiplier.

$$
a=\sum_{j=1}^{J} \sum_{i=1}^{i} \theta_{j i} M_{d_{j}}
$$


$M_{d_{j}}$ indicates the increase in employment in the region per naira of turnover with respect to the ith type of business generated within a similar type of business and other types of business that directly receive tourist expenditure.

$$
b=\sum_{j=1}^{J} \sum_{i=1}^{I} \theta_{j i}\left(M_{i}-M_{d_{i}}\right)
$$

$M_{i}$ is the increase in employment in the region per naira of turnover to the ith business types generated within that business type participating in the subsequent transaction flows:

$$
c=(\alpha+\beta+\sigma) \sum_{i=1}^{I} C_{i} M_{i}
$$

Equations (8), (9), and 10 are, respectively, the direct employment generation, the indirect employment generation, and the induced employment generation.

$$
M_{c r}=\sum_{j=1}^{J} \sum_{=j}^{I} N_{j} Q_{j} \theta_{j i} X_{i}+\left[\sum_{j=1}^{J} \sum_{i=1}^{I} N_{j} Q_{j} \theta_{j i} Y\left(\frac{1}{1-L \sum_{i=1}^{J} M_{i} Z_{i} Y_{i}}\right)\right] \sum_{i=1}^{I} M_{i} X_{i}
$$

Three baseline models are specified (Self-employment, Export, and Import):

Sem $=\alpha_{0}+\alpha_{1}$ Export $+\alpha_{2} \operatorname{Im}$ port $+\alpha_{3} n o \_$arriv $+\alpha_{4}$ oda $+\alpha_{5} p_{-} r e m+\alpha_{6}$ pop_lc $+\varepsilon_{1}$

Export $=\alpha_{0}+\alpha_{1} n o_{-}$arriv $+\alpha_{2} o d a+\alpha_{3} p_{-} r e m+\alpha_{4} p o p \_l c+\varepsilon_{2}$

$\operatorname{Im}$ port $=\alpha_{0}+\alpha_{1} n o \_$arriv $+\alpha_{2}$ oda $+\alpha_{3} p_{-} r e m+\alpha_{4} p o p_{-} l c+\varepsilon_{3}$

Where Sem denotes self-employment, Export denotes total export trade, Im port is total import trade, no_arriv is the total tourist arrival, oda represents overseas development assistance, $p_{-}$rem represents 
personal remittances, and pop_lc is the population residing in large cities. $\varepsilon_{1}=\varepsilon_{2}=\varepsilon_{3}=$ error term independently and identically distributed.

The Generalized Method of Moment GMM estimation technique is employed. It corrects an econometric model suspected with nonorthogonality among the regressors and error terms. The GMM estimation is one of the most important developments in time series econometrics.

Generally, consideration is given to $n$ equations accompanied by additive regression errors and that:

$$
E\left(q_{t}, \varepsilon_{t}\right)=0
$$

$q_{t}$ is a $m X n$ matrix of instruments, and $\varepsilon_{t}$ is a $n X 1$ vector of regression errors from the $n$ equations in existence. Let $\hat{W}$ be a $m X m$ positive definite weighting matrix emphasizing that $W$ may be sample dependent. Given that $s$ is the sample size and based on Hansen (1982), the $G M M$ estimator chooses $\rho$ that minimizes the function:

$\left[s^{-1} \sum_{t=1}^{s} g_{t}(\rho)\right]^{\prime} \hat{W}\left[s^{-1} \sum_{t=1}^{s} g_{t}(\rho)\right]$

Under general conditions, $\hat{\rho}=\sqrt{s}$, consistent and asymptotically normal.

Suppose the long-run variance $g_{t}\left(\rho_{0}\right)$ takes the form:

$\Omega=\sum_{j=-\infty}^{\infty} E g_{t}\left(\rho_{0}\right) g_{t-j}\left(\rho_{0}\right)^{\prime}$

The efficiency of $G M M$ is defined by choosing $W$ such that $\hat{W}^{-1} \rightarrow_{\rho} \Omega$ and hence $\hat{\Omega^{-1}}$, the weighting matrix. Given that $G_{t}$ is a $m X k$ matrix of derivatives of the orthogonality condition, just obtained at $\rho_{0}$ as follows:

$$
G_{t}=\frac{\partial g_{t}(\hat{\rho})}{\partial \rho}
$$


Defining $G$ as sample counterpart evaluated at the sample estimator of $\rho_{0}$; such that:

$$
\hat{G}=s^{-1} \sum_{t=1}^{s} \frac{\partial g_{t}(\rho)}{\partial \rho}
$$

The necessary condition:

$$
\hat{\rho}=\hat{G^{\prime}} \Omega^{-1}\left[s^{-1} \sum_{t=1}^{s} g_{t}(\hat{\rho})\right]=0
$$

It makes sense to observe that since $g_{t}=q_{t} \varepsilon_{t}$, then the necessary condition may be re-written as:

$$
\left[s^{-1} \sum_{t=1}^{s} z_{t} q_{t}\right]=0, \hat{z}_{t}=G^{\prime} \Omega^{-1} q_{t}, \hat{\varepsilon_{t}}=\varepsilon_{t}(\hat{\rho})
$$

With more moments than parameters, GMM takes a similar fashion observed in the instrumental variable estimation.

Data employed for this study was obtained from the World Development Indicators spanning the period 1991-2019, and, in some cases, missing data is inevitable.

\section{Estimation}

Table 1. Descriptive statistics

\begin{tabular}{llllllll}
\hline & SEM & Export & Import & no arriv & oda & p rem & pop lc \\
\hline Mean & 0.98 & 3.32 & 3.25 & 13.87 & 18.68 & -0.88 & 3.55 \\
Median & 1.26 & 3.54 & 3.36 & 13.83 & 18.71 & -0.65 & 3.68 \\
Std & 0.70 & 0.57 & 0.48 & 1.01 & 1.68 & 1.25 & 0.26 \\
Skew & 0.77 & -1.57 & -0.62 & -2.00 & 0.15 & -0.97 & -1.50 \\
Kur & 4.20 & 5.37 & 1.67 & 7.88 & 1.97 & 5.35 & 4.57 \\
J-B & 0.00 & 0.00 & 0.00 & 0.00 & 0.02 & 0.00 & 0.00 \\
\hline
\end{tabular}

The descriptive statistics in table 1 indicate that official development assistance has the highest mean and median values, with personal remittance flows having the lowest mean and median. Intuitively, the three countries concerned have a large size of development assistance compared to other financial flows. The relatively high standard deviation further demonstrates 
Management \& Economics Research Journal

the large size and volatility of development assistance in these countries. Jarque-Bera statistics which is above the 5\% level, shows that only total receipt from tourism has a normal distribution.

Table 2. GMM Estimation of SE, export and import equations

\begin{tabular}{|c|c|c|c|c|c|c|c|c|c|}
\hline \multicolumn{4}{|c|}{ DEP.VAR $\rightarrow$ SEM } & \multicolumn{3}{|l|}{ Export } & \multicolumn{3}{|c|}{ Import } \\
\hline & Coeff. & S.E & Prob & Coeff & S.E & Prob & Coeff & S.E & Prob \\
\hline $\mathrm{C}$ & 5.41 & 0.53 & 0.00 & 1.87 & 3.34 & 0.58 & 3.37 & 1.69 & 0.06 \\
\hline Export & 0.03 & 0.04 & 0.44 & ------ & ----- & ------ & ----- & ----- & ----- \\
\hline Import & 0.05 & 0.05 & 0.37 & ------ & ----- & ------ & ----- & ----- & ----- \\
\hline No arriv & -0.19 & 0.03 & 0.00 & 0.01 & 0.18 & 0.98 & -0.15 & 0.06 & 0.03 \\
\hline oda & 0.05 & 0.02 & 0.05 & 0.10 & 0.07 & 0.19 & 0.06 & 0.05 & 0.19 \\
\hline P rem & 0.06 & 0.05 & 0.21 & -0.71 & 0.30 & 0.02 & -0.29 & 0.15 & 0.06 \\
\hline pop_lc & -0.96 & -15.80 & 0.00 & -0.09 & 0.25 & 0.72 & 0.25 & 0.12 & 0.05 \\
\hline $\operatorname{ar}(1)$ & & & & 0.73 & & & 0.43 & & 0.00 \\
\hline $\mathrm{R}^{2}$ & 0.85 & & & 0.56 & & & 0.80 & & \\
\hline- & 0.81 & & & 0.47 & & & 0.76 & & \\
\hline$R^{2}$ & & & & & & & & & \\
\hline DW & 1.93 & & & 1.68 & & & 2.35 & & \\
\hline & 0.33 & & & 0.81 & & & 0.60 & & \\
\hline Prob.J - s & & & & & & & & & \\
\hline Inst. rank & 11 & & & 13 & & & 14 & & \\
\hline
\end{tabular}

From the GMM estimation in table 2 and starting with the selfemployment equation, a $10 \%$ increase in export trade leads to a significant increase in self-employment by about $0.3 \%$ and about $0.5 \%$ for a $1 \%$ increase in import trade. The direct relationship between the two is in line with the theoretical assertion that exporting always leads to higher labour demand and employment and, in this case, self-employment. Besides, tourists may identify business opportunities that could lead to export trade. The estimation shows that rising import results in employment and increased labour force participation. This may subsequently lead to a rising level of self-employment. Importation of notable raw materials may show a significant positive impact on domestic firms' performance through productivity increase. The number of tourist arrival relates negatively to self-employment growth in Ghana, Nigeria, and Cote d'Ivoire. A 1\% increase in tourist arrival declines self-employment by about $0.2 \%$. This demonstrates the low growth of the tourism industry in the three countries despite the potential, including natural features and land formation, creativity, and originality, among others. This seems to aggravate unemployment problems, most importantly in self-employment.

The official development assistance similarly shows an improvement in employment growth (0.05). Development assistance is expected to rebuild the economic structure with economic transformation, but 
sometimes the utilization of this particular within the unproductive sector calls for concern. Meanwhile, a 10\% increase in Personal remittance increases employment by $0.6 \%$, and by implication, it appears remittance flows help stimulate self-employment growth in the three selected countries. Population in the large city shows a negative relationship with selfemployment. The teeming population in the region is expected to compete for the same number of job applications, thereby reducing the chances of anyone securing. In the African region, existing competition makes selfemployers demand labour at relatively low wages as increased competition makes it difficult to find a job.

For the export and import equations, tourist arrival shows positive and negative effects on trade between exports (0.01) and imports (-0.15). The positive effect of tourist arrival on export is in line with the fact that international visitors tend to identify business opportunities that could thrive export sales and in which case such opportunities tend not to support import purchases. Development assistance stimulates export (0.1) and import growth (0.06) and is significant at the $10 \%$ level. This attests to the idea that foreign financial assistance can thrive in trade flows. However, personal remittance inflows significantly negatively influence exports (-0.71) and imports (-0.29) growth. Remittance flows are expected to increase productivity for export growth and subsequently increase foreign exchange earnings. This may also increase the importation of necessary raw materials for more productivity. Population in the large city also has a negative impact on export (-0.09) and a positive impact on import (0.25) trade. In bilateral trade, population serves as the market size and is expected to trigger the trade. The negative influence on export could be linked to low domestic production amidst the teeming population. The explanatory power of the explanatory variables is high in each of the scenarios except for the export equation, where only about $56 \%$ variation in the export growth is explained. The Durbin-Watson value shows that serial correlation between variables is not a major problem, having regulated by the first-order autoregressive scheme in the export and import equations which is positive and significant. The $\mathrm{p}$-value of $\mathrm{J}$ statistics is greater than the $5 \%$ significance level, hence the validity of the choice of instruments. 
\begin{tabular}{l|l||l} 
Management \& Economics Research Journal & Vol. 3 No. 1 (2021) & pp. 44-59
\end{tabular}

Table 3. Specification : les c lexport limport lno arriv loda lp_Rem lpop_largec

\begin{tabular}{cccc}
\hline Difference J-stats & Value & df & Prob. \\
\hline & 1.20 & 2 & 0.55 \\
\hline
\end{tabular}

Next is to examine the non-orthogonality conditions among the regressors, as shown by the results of the endogeneity test. For the selfemployment equation and given the probability value (0.55), the hypothesis that all the regressors are exogenous is accepted.

Table 4. Specification : lexport c lno arriv loda lp_Rem lpop_largec

\begin{tabular}{llll}
\hline Difference J-stats & Value & df & Prob. \\
\hline & 0.94 & 2 & 0.63 \\
\hline
\end{tabular}

In line with the above, the hypothesis that all the regressors in the export equation are exogenous is also accepted following a probability value of 0.63 .

Table 5. Specification : limport c lno arriv loda lp_Rem lpop_largec

\begin{tabular}{llll}
\hline Difference J-stats & Value & df & Prob. \\
\hline & 0.26 & 2 & 0.88 \\
\hline
\end{tabular}

In the same way, regressors in the import equation are also exogenous, given the probability value of 0.88 .

The results of tables (3), (4), and (5) attest to the justification for the GMM estimation method.

\section{Conclusion}

The increasing level of international tourism activities has placed it as an engine of growth and development as it contributes to employment opportunities despite some major global obstacles. The LDCs have benefited from the positive externalities of tourism activities, as demonstrated in the increased earnings from export trade which create opportunities for competitiveness. Likewise, trade integration also enhances tourist attraction through investment in infrastructure that can further strengthen the relationship with the results that employment growth is enhanced. The panel GMM was employed to estimate the relationship between tourism and trade and employment growth, specifically focusing on self-employment. Export and Import trade, development assistance, and personal remittance flows were major drivers of self-employment growth in Ghana, Nigeria, and Cote d'Ivoire. However, several tourist arrivals 
negatively impacted self-employment but encouraged export trade.

Major policy implications here are mainly for the countries in question to facilitate trade through a less stringent trade policy framework for tourist attraction and boost employment opportunities. Likewise, the need to have effective linkages through ensuring better infrastructure would enhance the free flow of tourism activities and facilitate domestic trade and self-employment. There should be regulation of the environment from activities that can lead to the outbreak of epidemics which could effectively retard trade, tourism, and hence employment. Tourism activities are expected to improve trade; hence trade integration should be enhanced, and tourists should be encouraged to embark on activities that can facilitate trade for foreign exchange earnings in their countries.

\section{Declaration of conflicting interests}

The author(s) declared no potential conflicts of interest with respect to the research, authorship, and/or publication of this article.

\section{References}

Aradhyula S., \& Tronstad R. (2003). Does Tourism Promote Cross-Border Trade? American Journal of Agricultural Economics, 85(3), 569579. https://doi.org/10.1111/1467-8276.00456

Balaguer, J., \& Cantavella-Jorda, M. (2002). Tourism as a long-run economic growth factor, the Spanish case. Applied Economics, 34(7), 877-884. https://doi.org/10.1080/00036840110058923

Bhagwati, J. N. (1978). Foreign trade regimes and economic development, anatomy and consequences of exchange control regimes. New York: National Bureau of Economic Research.

Bryon, J. (2012). Tour guides as storytellers - from selling to sharing. Scandinavian Journal of Hospitality and Tourism, 12(1), 27-43. https://doi.org/10.1080/15022250.2012.656922

Chaisumpunsakul, W., \& Pholphirul, P. (2018). Does international trade promote international tourism demand? Evidence from Thailand's trading partners. Kasetsart Journal of Social Sciences, 39, 393400. http://doi.org/10.1016/j.kjss.2017.06.007

Dwyer, J.F., McPherson, E.G., Schroeder, H.W., \& Rowntree, R.A. (1992). Assessing the benefits and costs of the urban forest. Journal of Arboriculture, 18 (5), 227-234.

Ekanayake, E. M., \& Long, A. E. (2012). Tourism Development and Economic Growth in Developing Countries. The International 
\begin{tabular}{l||l|l} 
Management \& Economics Research Journal & Vol. 3 No. 1 (2021) & pp. 44-59
\end{tabular}

Journal of Business and Finance Research, 6(1), 51-63. https://www.theibfr.com/download/IJBFR/2012-ijbfr/ijbr-v6n12012/IJBFR-V6N1-2012.pdf

González, A. (2017). Sustainable tourism to sustainable development. International Trade Centre

Henderson, D. M., \& Cousins, R. L. (1975). The economic impact of tourism: a case study in Greater Tayside. Tourism and Recreation Research Unit. Research Report 13. Edinburgh: University of Edinburgh.

Khan, H., Toh, R. S., \& Chua, L. (2005). Tourism and Trade: Cointegration and Granger Causality Tests. Journal of Travel Research, 44(2), 171-176. https://doi.org/10.1177/0047287505276607

Kulendran, N, Wilson, K. (2000). Is there a relationship between international trade and international travel, Applied Economics, 32, 1001-1009? https://doi.org/10.1080/000368400322057

Leitão, N. C. (2010). Does trade help to explain tourism demand? The case of Portugal. Theoretical and Applied Economics, 17 (3/544), 63-74.

Oigenblick, L. \& Kirschenbaum, A. (2002). Tourism and Immigration Comparing Alternative Approaches. Annals of Tourism Research, 29 (4), 1086-1100. https://doi.org/10.1016/S0160-7383(02)00023-3

Rusu, S., Isac, F., \& Cureteanu, R. (2016). Worldwide tourism entrepreneurship, a global perspective. Facultatea de Management Agricol, 17(4), 64-68.

Santana-Gallego, M., Ledesma-Rodrı 'guez, F., \& Pe 'rez-Rodrı 'guez, J.V. (2011). Tourism and trade in OECD countries. A dynamic heterogeneous panel data analysis. Empirical Economics, 41(2), 533-554. https://doi.org/10.1007/s00181-011-0477-9

Shan, J., \& Wilson, K. (2001), Causality between trade and tourism: empirical evidence from China, Applied Economics Letters, 8, 279 283. https://doi.org/10.1080/135048501750104114

Sinclair, M.T., \& Stabler, M. (1997), The Economics of Tourism, Routledge, London.

Taskov, N., Metodijeski, D., Dzaleva, T., \& Filipovski, O. (2011). Entrepreneurship in tourism industry leads to business benefits. In $2^{\text {nd }}$ Biennial International Scientific Congress: The influence of Tourism on Economic Development (pp. 1-12). Retrieved from http://citeseerx.ist.psu.edu/viewdoc/download?doi=10.1.1.472.4645 $\&$ rep $=$ rep $1 \&$ type $=$ pdf

Tsui, W. H. K., \& Fung, M. K. Y. (2016). Causality between business travel and trade volumes: Empirical evidence from Hong Kong. Tourism 
Management,

52 ,

$395-404$.

https://doi.org/10.1016/j.tourman.2015.07.010

Turner, L.W., \& Witt, S.F. (2001). Forecasting tourism using univariate and multivariate structural time series models. Tourism Economics, 7 (2). 135-147. https://doi.org/10.5367\%2F000000001101297775

UNWTO (2018).

Tourism

Highlights. https://doi.org/10.18111/9789284419876

Webster, A., Fletcher J., \& Hardwick, P. (2007). Tourism and empirical applications of international trade theory: a multi-country analysis, Tourism Economics, 2007, 13 (4), 657-674. https://doi.org/10.5367/000000007782696041

Witt, S. Witt, C. (1995). Forecasting Tourism Demand: A Review of Empirical Research, International Journal of Forecasting, 11(3), 447-475. https://doi.org/10.1016/0169-2070(95)00591-7 